\title{
Characterization of Nucleocapsid-M Protein Interaction in Murine Coronavirus
}

\author{
${ }^{1,2}$ KRISHNA NARAYANAN AND ${ }^{1,2}$ SHINJI MAKINO

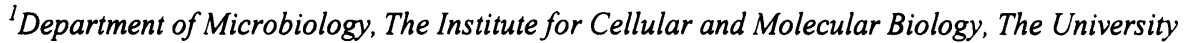 \\ of Texas at Austin, Austin, Texas 78712: ${ }^{2}$ Department of Microbiology and Immunology, The \\ University of Texas Medical Branch at Galveston, Galveston, Texas 77555-1019.
}

\section{INTRODUCTION}

Coronavirus is a large enveloped virus containing a $27-32 \mathrm{~kb}-$ long singlestranded, positive-sense RNA genome (Lee et al 1991). Coronaviruses generally have three envelope proteins $\mathrm{S}, \mathrm{M}$, and $\mathrm{E}$. N protein and the viral genomic RNA form a helical nucleocapsid (Macnaughton et al 1978).

Coronavirus assembly is presumably dependent on protein-protein and protein-RNA interactions. Interactions between viral envelope protein(s) and the viral internal component are rather poorly characterised. Sturman et al. showed that MHV envelope glycoproteins (M and S) and the MHV nucleocapsid are separated by solubilization of the viral membrane with nonionic detergent NP40 at $4^{\circ} \mathrm{C}$ followed by sucrose gradient centrifugation. Incubation of the NP40-disrupted $\mathrm{MHV}$ at $37^{\circ} \mathrm{C}$ resulted in the association of $\mathrm{M}$ protein and N protein-genomic RNA complex (Sturman et al 1980), indicating that this interaction is temperature-dependent.

The present study examined the interaction between the viral envelope protein(s) and viral internal component in virus particles. We showed the interaction between $\mathrm{M}$ protein and $\mathrm{N}$ protein-genomic RNA complex in mature virus particles. This interaction was ionic in nature. Characterisation of bromelain-treated MHV showed that the interaction between M protein and $\mathrm{N}$ protein-genomic RNA complex in bromelain-treated MHV was not disrupted under a high salt condition. 


\section{MATERIALS AND METHODS}

\subsection{Viruses and cells}

The plaque-cloned A59 strain of MHV (Baric et al 1990) was used. Mouse DBT cells (Hirano et al 1974) were used for the growth of viruses.

\subsection{Labelling of virion proteins and purification of viruses}

For labelling of virion proteins, $\left[{ }^{35} \mathrm{~S}\right]$ methionine was added to virusinfected cells at $7.5 \mathrm{~h}$ p.i. and culture fluids were collected $12 \mathrm{~h}$ p.i. (Makino et al 1991). MHV particles were purified by sucrose gradient centrifugation and viral proteins, from purified virus particles, were analysed by SDSPAGE as described previously (Kim et al 1997).

\subsection{Disruption of virion with NP40}

To disrupt virion under a low salt condition, purified viruses were pelleted and incubated in a low salt buffer (NTE buffer; $0.1 \mathrm{M} \mathrm{NaCl}, 0.01 \mathrm{M}$ Tris- $\mathrm{HCl}$ [pH 7.5], $0.001 \mathrm{M}$ EDTA) containing $0.25 \% \mathrm{NP} 40$, for $30 \mathrm{~min}$ at $4^{\circ} \mathrm{C}$. For high salt treatment, a high salt buffer (NTE buffer $+0.25 \mathrm{M} \mathrm{KCl}$ ), containing $0.25 \% \mathrm{NP} 40$, was used. The detergent-treated viruses were then layered over a $10-65 \%$ discontinuous sucrose gradient, made in NTE buffer, and sedimented at $38,000 \mathrm{rpm}$ for $5 \mathrm{~h}$ at $4^{\circ} \mathrm{C}$. Fractions were collected from the bottom of the gradient and the viral proteins in these fractions were pelleted by centrifugation at $38,000 \mathrm{rpm}$ for $2.5 \mathrm{~h}$ at $4^{\circ} \mathrm{C}$ on a Beckman SW40 rotor.

\subsection{Characterisation of virion RNA}

Virus-specific RNAs were extracted from the pelleted sucrose gradient fractions and Northern blot analysis was performed with a ${ }^{32} \mathrm{P}$-labeled, random-primed probe corresponding to the 5'-end of MHV genomic RNA as described previously (Fosmire et al 1992).

\section{RESULTS}

We characterised the interaction between viral envelope protein(s) and the viral internal component. $\left[{ }^{35} \mathrm{~S}\right]$ methionine-labelled, purified MHV was treated with a low salt buffer, containing NP40. SDS-PAGE analysis of 
pelleted proteins, in each fraction, showed the cosedimentation of both $M$ protein and $\mathrm{N}$ protein (Fig. 1A). The highest amount of both proteins was near the bottom of the gradient. S protein was present only near the top of the gradient. To examine the location of viral genomic RNA in the gradient, nonradiolabeled purified MHV was treated under the same condition. Northern blot analysis of virion RNA, extracted from the pelleted fractions, showed that the distribution of virion RNA was similar to that of $\mathrm{N}$ and $\mathrm{M}$ proteins (Fig. 1B). These data indicated that treatment of MHV in a low salt buffer, containing NP40, resulted in the aggregation of genomic RNA, N protein and $\mathrm{M}$ protein, which sedimented near the bottom of the gradient. $\mathrm{S}$ protein was separated from the aggregates of $\mathrm{M}$ protein, $\mathrm{N}$ protein and genomic RNA. Cosedimentation of $\mathrm{M}$ protein and $\mathrm{N}$ protein-genomic RNA complex was due to the interaction between $\mathrm{M}$ protein and $\mathrm{N}$ proteingenomic RNA complex, because anti-N protein antibody coprecipitated both $\mathrm{M}$ protein and MHV genomic RNA from the sucrose fractions (data not shown).

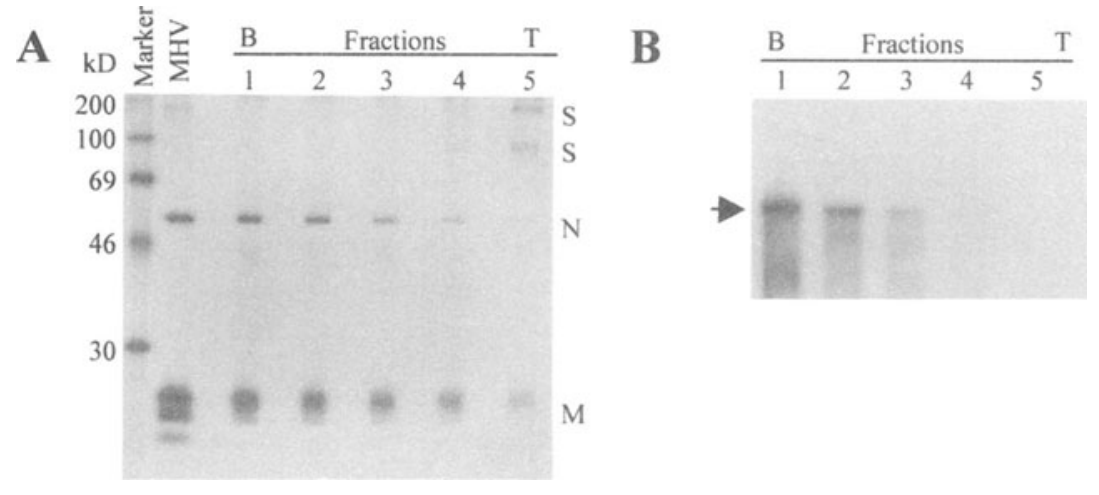

Figure 1. Characterisation of interaction after treatment of MHV with a low salt buffer, containing NP40. (A) ${ }^{35}$ S-labeled, partially purified MHV was incubated in a low salt buffer, containing NP40, as described in Materials and Methods, and analysed by SDS-PAGE. (B) Nonradiolabeled MHV was treated under the same condition and virion RNA was analysed by Northern blot analysis. Arrow; MHV genomic RNA. B and T represent the bottom and the top of the gradient, respectively.

Next we attempted to separate envelope $M$ protein from the aggregation of $\mathrm{M}$ protein, $\mathrm{N}$ protein and viral genomic RNA by incubating MHV in a high salt buffer, containing NP40. If the interaction between envelope M protein and the N protein-genomic RNA complex is ionic in nature, then this interaction may be susceptible to a high salt treatment. $\left[{ }^{35} \mathrm{~S}\right]$ methioninelabelled purified MHV was incubated in a high salt buffer, containing NP40. SDS-PAGE analysis of each fraction showed that $M$ protein did not cosediment with $\mathrm{N}$ protein; major peak of $\mathrm{N}$ protein was in fractions 2 and 3 
while that of $\mathrm{M}$ protein was in fractions 5 and 6 (Fig. 2A). S protein sedimented to the top of the gradient. Northern blot analysis of each fraction showed that most of the viral genomic RNA cosedimented with N protein to fraction 2 (Fig. 2B). These data indicated that incubation of MHV under a high salt condition did not disrupt the interaction between viral genomic RNA and some, but not all, N protein, while the same incubation condition disrupted most of the interaction between $\mathrm{M}$ protein and the $\mathrm{N}$ proteingenomic RNA complex. Susceptibility, of the interaction between M protein and N protein-genomic RNA complex to a high concentration of salt, has not been reported previously in coronaviruses; this susceptibility suggests an ionic interaction between $\mathrm{M}$ protein and $\mathrm{N}$ protein-genomic RNA complex.

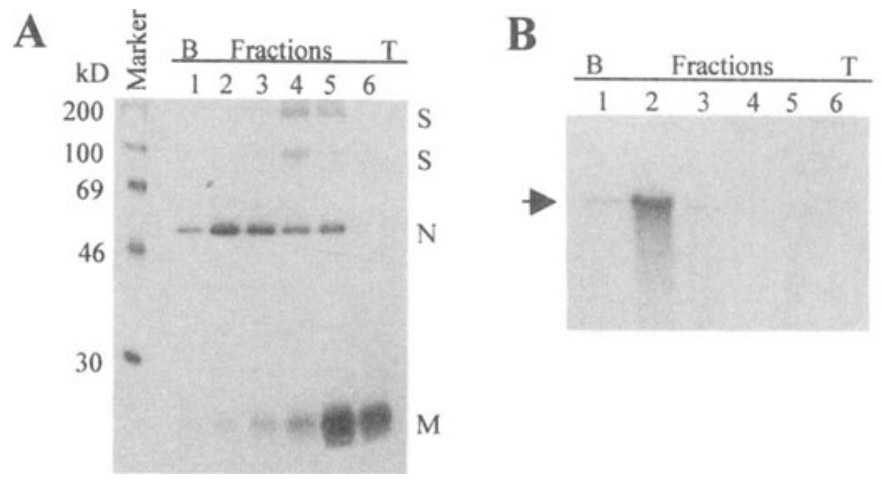

Figure 2. Characterisation of interaction after treatment of MHV with a high salt buffer, containing NP40. (A) ${ }^{35}$ S-labeled partially purified MHV was incubated in a high salt buffer, containing NP40, and treated as described in the legend of Fig. 1A. (B) Nonradiolabeled MHV was treated under the same condition as described in A and virion RNA was analysed by Northern blot analysis. Arrow; MHV genomic RNA.

Next we characterised the interaction between $\mathrm{M}$ protein and $\mathrm{N}$ proteingenomic RNA complex in bromelain-treated MHV. Previous studies have shown that bromelain-treated MHV has an intact $\mathrm{N}$ protein and an $18 \mathrm{kD} \mathrm{M}$ protein (Makino et al 1983); most probably the $18 \mathrm{kD}$ protein represented $\mathrm{M}$ protein lacking the N-terminal ectodomain (Makino et al 1983). $\left[{ }^{35} \mathrm{~S}\right]$ methionine-labelled, partially purified virus was treated with bromelain and the bromelain-treated virus suspension was purified as described previously (Makino et al 1983). Purified bromelain-treated MHV was incubated in the low salt buffer, containing NP40, or in the high salt buffer, containing NP40. SDS-PAGE analysis of gradient fractions showed that the $18 \mathrm{kD}$ M protein fragment and $\mathrm{N}$ protein cosedimented, after treatment with low salt buffer as well as high salt buffer (Fig. 3). These data indicated that the interaction between $18 \mathrm{kD}$ M protein fragment and $\mathrm{N}$ protein-genomic RNA complex was not disrupted under high salt condition. Characterisation of viral 
genomic RNA showed that genomic RNA cosedimented with $\mathrm{N}$ protein under both buffer conditions (data not shown).
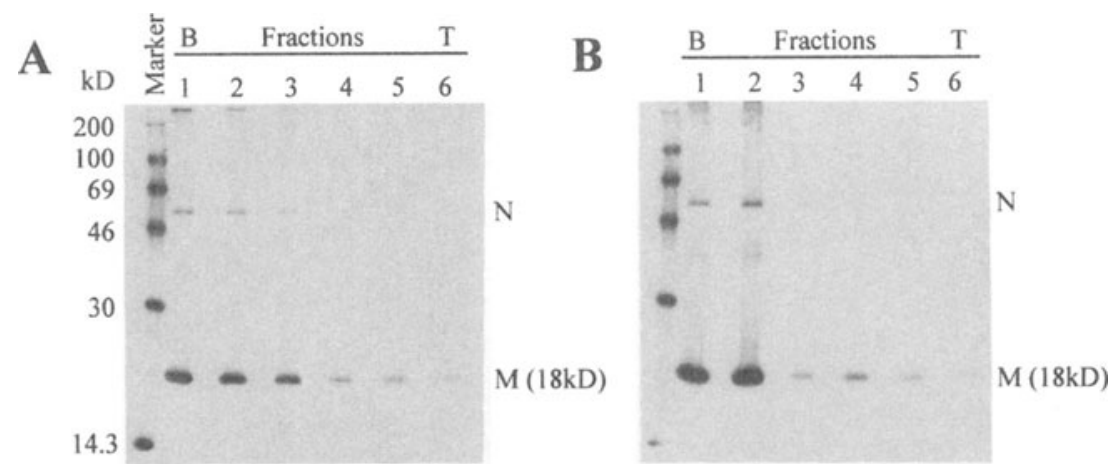

Figure 3. Characterisation of bromelain-treated MHV. ${ }^{35}$ S-labeled, bromelain-treated MHV was incubated in a low salt buffer, containing NP40 (A) or in a high salt buffer, containing NP40 (B) as described in the legend of Fig.1A and samples were analysed by SDS-PAGE.

\section{DISCUSSION}

The present study demonstrated the interaction between $\mathrm{M}$ protein and $\mathrm{N}$ protein-genomic RNA complex in mature virus particles; this interaction appeared to be ionic in nature and was not disrupted under low salt condition. Our recent data revealed that interaction between $\mathrm{M}$ protein and $\mathrm{N}$ protein-genomic RNA complex exists in MHV-infected cells (Narayanan et $a l$ in press); the present study demonstrated that the interaction between $\mathrm{M}$ protein and $\mathrm{N}$ protein-genomic RNA complex, initiated in MHV-infected cells, was maintained in mature MHV particles. Our data in the present study were consistent with the data presented by Sturman et al. (Sturman et al 1980).

Interaction between $\mathrm{M}$ protein and $\mathrm{N}$ protein-genomic RNA complex in bromelain-treated MHV was not disrupted under a high salt condition, indicating that removal of the short ectodomain of $M$ protein affected the property of its cytoplasmic tail, which probably interacts with $\mathrm{N}$ proteingenomic RNA complex. Removal of the envelope $M$ protein ectodomain may extensively alter $\mathrm{M}$ protein conformation, and this altered conformation may stabilise the interaction between $\mathrm{M}$ protein and $\mathrm{N}$ protein-genomic RNA complex. 


\section{ACKNOWLEDGEMENTS}

This work was supported by the Public Health Service Grant AI29984 from the National Institutes of Health.

\section{REFERENCES}

Baric, R. S., Fu K., Schaad, M. C., and Stohlman, S. A., 1990, Establishing a genetic recombination map for murine coronavirus strain A59 complementation groups. Virology 177:646-656.

Fosmire, J. A., Hwang K., and Makino, S., 1992, Identification and characterisation of a coronavirus packaging signal. J. Virol. 66:3522-3530.

Hirano, N., Fujiwara K., Hino, S., and Matsumoto, M., 1974, Replication and plaque formation of mouse hepatitis virus (MHV-2) in mouse cell line DBT culture. Arch. Gesamte. Virusforch. 44:298-302.

Kim, K. H., Narayanan, K., and Makino, S., 1997, Assembled coronavirus from complementation of two defective interfering RNAs. J. Virol. 71:3922-3931.

Lee, H.-J., Shieh, C.-K.,. Gorbalenya, A. E., Eugene, E. V., La Monica, N., Tuler, J., Bagdzhadzhyan, A., and Lai, M. M. C., 1991, The complete sequence (22 kilobases) of murine coronavirus gene 1 encoding the putative proteases and RNA polymerase. Virology 180:567-582.

Macnaughton, M. R., Davies, H. A., and Nermut, M. V., 1978, Ribonucleoprotein-like structures from coronavirus particles. J. Gen. Virol. 39:545-549.

Makino, S., Taguchi, F., Hayami, M., and Fujiwara, K., 1983, Characterisation of small plaque mutants of mouse hepatitis virus, JHM strain. Microbiol. Immunol. 27:445-454.

Makino, S., Joo, M., and Makino, J. K., 1991, A system for study of coronavirus mRNA synthesis: a regulated, expressed subgenomic defective interfering RNA results from intergenic site insertion. J. Virol. 65:6031-6041.

Narayanan, K., Maeda, A., Maeda J., and Makino, S., Characterisation of the coronavirus M protein and nucleocapsid interaction in infected cells. In press.

Sturman, L. S., Holmes, K. V., and Behnke, J., 1980, Isolation of coronavirus envelope glycoproteins and interaction with the viral nucleocapsid. J. Virol. 33:449-462. 